THE UTILISATION OF THE RIGHT OF CHILDREN TO SHELTER TO ALLEVIATE POVERTY IN SOUTH AFRICA

ISSN 1727-3781

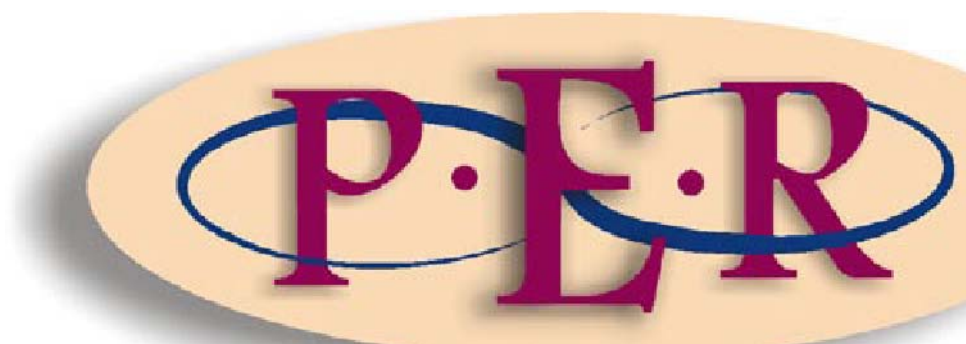

2004 VOLUME 7 No 1 


\title{
THE UTILISATION OF THE RIGHT OF CHILDREN TO SHELTER TO ALLEVIATE POVERTY IN SOUTH AFRICA
}

\author{
I Mc Murray and L Jansen van Rensburg ${ }^{3}$ North-West University \\ (Potchefstroom Campus)
}

\section{$1 \quad$ Introduction}

In 2002, it was estimated that 11 million children (between the ages of 0-18) are living in dire poverty in South Africa on less than R200 per capita per month (R245 in 2002 real terms), and therefore living on less than half the minimal R400 per capita per month required to meet their basic needs, and 14.3 million children are living in poverty on less than R400 per capita per month (R490 in 2002 terms). Child poverty is on the increase. Between 1995 and 1999 the rate of child poverty in South Africa on a poverty line of R400 per capita per month increased from $64.7 \%$ to $75.8 \%$ and the rate of children in dire poverty calculated on a poverty line of R200 per capita per month increased by $19.2 \%$ from $38.9 \%$ to $58.1 \%$.

These children face shortages of food, clothing, and shelter. They also lack access to basic services. In the light of this, their basic human dignity and other fundamental rights are denied. Therefore, it is not surprising that most of South Africa's children lack basic shelter and are often homeless. This prevailing manifestation of poverty needs to be addressed effectively. One way of addressing this is through a rights based approach whereby socioeconomic rights are realised to the poorest of the poor.

1 This article forms part of a National Research Foundation Project titled: "The utilisation of socioeconomic rights to alleviate the plight of poor children in South Africa." The financial assistance of the National Research Foundation: Social Sciences and Humanities towards this research is hereby acknowledged. Opinions expressed and conclusions arrived at are those of the authors and are not necessarily to be attributed to the National Research Foundation.

2 North-West University (Potchefstroom Campus).

3 North-West University (Potchefstroom Campus).

4 Joint Submission to the Portfolio Committee 2003 http://www.pmg.org.za/docs/2003/appendices/030922joint.htm Mar 2004.

5 Compare Government of the Republic of South Africa v Grootboom 200011 BCLR 1169 (CC) par [23]. Hereafter referred to as the Grootboom Constitutional Court case.

6 Jansen van Rensburg 2002 PER http://www.puk.ac.za/law/per/documents/special\%20edition\%202002/linda.doc Mar 2004. See Goldewijk and de Gaay Fortman Where Needs Meet Rights. 
For the first time in South African history the Constitution of the Republic of South Africa, $1996^{7}$ entrenches numerous socio-economic rights. One of these socio-economic rights is contained in section 26 that grants everyone the right to have access to adequate housing and section 28 that grants every child the additional right to basic shelter among others.

This article will focus on the utilisation of the right to shelter of the child to alleviate poverty. Essential to this discussion is an effective understanding of the right to basic shelter as entrenched by section 28 of the Constitution in conjunction with the right of access to adequate housing conferred on everyone by virtue of section 26. This will be achieved by studying the general working of such rights including their limitations and enforcement.

\section{Poverty affecting South African children}

Poverty can be defined as the condition of having insufficient resources or income to enable a person to consume the goods and services required for a secure and healthy life. In its extreme form, poverty is a lack of basic human resources, such as adequate housing or shelter, clean water, nutritious food and health services. ${ }^{8}$ Poverty involves more than the suffering associated with lack of income. It also pertains to an inability to develop human capabilities, and to suffering attendant on physical insecurity and abuse and economic vulnerability.

Poverty has many causes, some of them very basic. In most cases, the causes and effects of poverty interact, so that what makes people poor also creates conditions that keep them poor. The accepted general factors that may lead to poverty include: overpopulation; the unequal distribution of resources in the world economy; inability to meet high standards of living and costs of living; inadequate education and employment opportunities; environmental degradation; certain economic and demographic trends; and welfare incentives.

In the South African context, a number of factors contributing to the existence of poverty can be identified. These are:

7 Constitution of the Republic of South Africa, 1996. Hereafter referred to as the Constitution.

8 Jackson and Jackson Introduction to Political Science 407; Venter Government and Politics 322.

9 Venter Government and Politics 407; Streak 2000 http://www.idasa.org.za May 2003.

10 Streak 2001 http://www.idasa.org.za May 2003.

11 May 1998 http://www.und.ac.za May 2003. 
- $\quad$ The impact of apartheid, which stripped people of their assets (especially land), distorted economic markets and social institutions through racial discrimination and resulted in violence and destabilisation;

- The undermining of the asset base of individuals, households and communities, through illhealth, over-crowding, environmental degradation, the miss use of resources, discrimination, and social isolation; and

- $\quad$ The impact of a disabling state, which included the behaviour and attitudes of government officials, the absence of information concerning rights, roles and responsibilities and the lack of accountability at all levels of government.

Poverty has wide-ranging and often devastating effects on children. Many of its effects, such as homelessness and malnutrition, result directly from having too little income or too few resources. Certain studies have also concluded that children who live a life of poverty are more susceptible to an adult life of crime and other problems such as depression, which can contribute to criminal behaviour. Furthermore, poverty tends to perpetuate itself. In many cases, poor children have become accustomed to the mindset that keeps them from getting out of poverty. These children then grow up to be poor adults earning lower than average incomes.

\section{The implementation of children's socio-economic rights to alleviate poverty}

It is submitted that significant progress can be made in the fight against poverty through effective realisation and enforcement of socio-economic rights, especially those conferred upon children. The Constitutional Court ${ }^{13}$ has recently confirmed this when it stated that the realisation of socio-economic rights is key to the advancement of a democratic society based on human dignity, freedom, and equality. The utilisation of children's socio-economic rights as a response to poverty requires a multi-sectoral, multi-faceted approach, which relies heavily on

12 Streak 2001 http://www.idasa.org.za May 2003, see also Motala 2001 http://www.childrensrightscentre.co.za/topics/poverty.html May 2003; Committee of Inquiry into a Comprehensive System of Social Security for South Africa Protecting the Children 55.

13 Grootboom Constitutional Court case par [23]. 
social policies and incorporates poverty alleviating programmes, integrated development plans, capacity development of communities, service delivery and social security.

\section{Children's socio-economic rights in the South African Constitution}

The Constitution entrenches children's rights in section $28 .^{15}$ The purpose of section 28 is to protect children in situations where they are particularly vulnerable. In this respect, the additional rights in section 28 enhance the protection afforded to everyone (including children) in the rest of the Bill of Rights. Section 28(1)(c) entrenches socio-economic rights for children that supplement the general socioeconomic rights to adequate housing, health care, nutrition and social security. ${ }^{16}$ This section places a duty on the state to ensure that a child is provided with these basic needs. The state must also ensure that the family of the child is provided with the means to support those needs.

\subsection{Children's right to basic shelter}

\subsubsection{The state's general obligations in terms of the right to basic shelter}

Traditionally, a Constitution is only seen as a protective device in so far that it places a duty on the state to refrain from interfering with the rights of individuals. ${ }^{18}$ This limited notion is rejected by the Constitution, which includes an obligation clause in the form of section 7(2).

14 Motala 2001 http://www.childrensrightscentre.co.za/topics/poverty.html May 2003.

15 S 28 of the Constitution reads: "(1) Every child has the right - (a) to a name and a nationality from birth;

(b) to family care, parental care, or appropriate alternative care when removed from the family environment; (c) to basic nutrition, shelter, basic health care services, and social services; (d) to be protected from maltreatment, neglect, abuse, or degradation; (e) to be protected from exploitative labour practices; (f) not to be required or permitted to perform work or provide services that - (i) are inappropriate for a person of that child's age; or (ii) place at risk the child's well-being, education, physical or mental health, or spiritual, moral, or social development; (g) not to be detained except as a measure of last resort, in which case, in addition to the rights a child enjoys under sections 12 and 35, the child may be detained only for the shortest appropriate period of time, and has the right to be - (i) kept separately from detained persons over the age of 18 years; and (ii) treated in a manner, and kept in conditions, that take account of the child's age; (h) to have a legal practitioner assigned to the child by the state, and at state expense, in civil proceedings affecting the child, if substantial injustice would otherwise result; and

(i) not to be used directly in armed conflict, and to be protected in times of armed conflict. (2) A child's best interest is of paramount importance in every matter concerning the child. (3) In this section, "child" means a person under the age of 18 years."

16 Own emphasis.

17 De Waal, Currie and Erasmus Bill of Rights 457; Davis, Cheadle and Haysom Fundamental Rights 265-266.

18 De Waal, Currie and Erasmus Bill of Rights 433; De Vos 1997 SAJHR 78; Jansen van Rensburg and Olivier 2001 Law, Democracy and Development 87. 
Section 7(2) reads: "The state must respect, protect, promote, and fulfil the rights in the Bill of Rights."

Therefore, in terms of section 7(2), the state no longer only has a duty to respect the socioeconomic rights of children, but also to protect, promote and fulfil them along with the other rights entrenched in the Bill of Rights.

This obligation to respect the right to basic shelter entrenches the traditional notion that the state must refrain from interfering with the rights of individuals, in other words, the state must respect the autonomy of the individual. ${ }^{19}$ Thus, on a primary level, the state must refrain from infringing a child's right to shelter. This duty also entails that the state may not promulgate legislation, nor act in a manner which would deprive a child of his or her right to basic shelter. An example of infringement of the duty to respect the right to basic shelter would be where children in child headed households are evicted from temporary shelter, or where parents are arbitrarily deprived of their access to adequate housing causing them not to be able to provide their children with shelter.

This obligation to protect the right to basic shelter places a positive duty on the state to ensure the effective enjoyment of the right. This entails that the state must create a legal framework in which the right to basic shelter can be realised without undue interference from other private parties. ${ }^{20}$ Thus, the state must protect individuals from interference with their social and economic well-being. ${ }^{21}$ For example, the state must ensure that children and their families are not evicted arbitrarily from their shelter or other forms of housing by private persons.

The duty to promote and fulfil the right to basic shelter entails that the state must ensure that all people are aware of their rights, whereas the duty to fulfil requires positive assistance from the state to ensure the full realisation of the rights in question.

Depending on the formulation of the rights, they could include a duty of the state to provide resources to fulfil an individual's basic social and economic needs directly. ${ }^{23}$ However, most socio-economic rights in the Constitution are internally limited. For example, section 26(2)

19 De Vos 1997 SAJHR 80; Jansen van Rensburg and Olivier 2001 Law, Democracy and Development 88; De Vos 1995 SAPL 253; Himes Implementing the CRC 15.

20 De Vos 1997 SAJHR 83; De Vos 1995 SAPL 254; Himes Implementing the CRC 15-16. See also Jansen van Rensburg and Olivier 2001 Law, Democracy and Development 89.

21 De Vos 1997 SAJHR 83.

22 De Vos 1997 SAJHR 86; De Vos 1995 SAPL 255; Himes Implementing the CRC 16.

23 De Vos 1997 SAJHR 86, De Vos 1995 SAPL 255; Himes Implementing the CRC 16. 
states that "the state must take reasonable legislative and other measures, within its available resources, to achieve the progressive realisation of [the right to adequate housing]".

The effective realisation of children's socio-economic rights has proven to be no simple matter and the seemingly less limited wording of section 28(1)(c) has not improved the situation. The question that should be asked in this regard is who is primarily responsible for providing basic shelter for children as envisaged by section 28(1)(c) of the Constitution?

In terms of the common law, parents have the primary duty to provide shelter, food, clothing and basic support to their children. This duty has been incorporated into legislation such as the Child Care Act 74 of 1983 , which states that parents who are able to provide care for their children but fail to do so are guilty of a criminal offence. ${ }^{25}$ Therefore, section 28(1)(b), which provides for the right to parental care and family life, together with section $8(3)^{26}$ of the Constitution provide that the primary responsibility to care for children rests on the parents. The state will only intervene when the parents are unable to fulfil their responsibilities. ${ }^{27}$ This is in line with the international rules formulated in articles 18 and 27(3) of the United Nations Convention on the Rights of the Child, and has recently been confirmed by the Constitutional Court in the Grootboom case.

When reading section 28(1)(b) together with section 28(1)(c), the question may be asked whether the state, when obligated to intervene and provide children with basic shelter, is also obligated to provide shelter to their parents. To answer this question, the relationship between section 26 and 28(1)(c) must be examined.

24 Child Care Act 74 of 1983 . Hereafter referred to as the 1983 Child Care Act.

25 Section 50(2) of the 1983 Child Care Act.

26 The horizontal application of the Bill of Rights is at present a heavily debated subject. For purposes of this article, a full discussion is not necessary. S 8(3) of the Constitution reads: "A provision of the Bill of Rights binds a natural or juristic person if, and to the extent that, it is applicable, taking into account the nature of the right and any duty imposed by the right."

27 De Waal, Currie and Erasmus Bill of Rights 457; Davis, Cheadle and Haysom Fundamental Rights 265-266.

28 Grootboom Constitutional Court case par [75]. 


\subsubsection{The relationship between section 26 and section 28(1)(c)}

The relationship between sections 26 and 28(1)(c) has been addressed by the High Court in Grootboom v Oostenberg Municipality and Others, and subsequently by the Constitutional Court in the Grootboom case.

Mrs Irene Grootboom along with the other applicants ${ }^{30}$ were rendered homeless after being evicted illegally from their informal settlements, which were situated on land earmarked for low-cost housing by the Cape Metro Land Programme. In the application before the High Court, they pleaded for an order requiring local government to provide them with adequate basic shelter or housing until they obtained permanent accommodation or other relief. ${ }^{31}$ The applicants firstly based their claim on section 26 of the Constitution, which provides everyone the right of access to adequate housing, which is limited by section 26(2). Secondly, the claim was based on section 28(1)(c), which provides children the right to basic shelter.

The High Court drew a distinction between section 26 and section 28(1)(c). Concerning the right of access to adequate housing, the court concluded that this provision does place a duty on the state to provide for the progressive realisation of the right to access to adequate housing within budget constraints. Thus, according to the Court's interpretation of section 26(1) in light of section 26(2), these provisions do not impose an obligation on the state to provide housing to everyone on demand. ${ }^{34}$ The simple reason for this conclusion is the fact that the realisation of any socio-economic right is subject to the availability of resources.

The second part of the High Court judgement addressed the children's shelter claim in terms of section 28(1)(c). The Court held that this provision imposed an obligation on the state to provide shelter to children if the parents were unable to do so. The Court went on to say:

29 Grootboom v Oostenberg Municipality 20003 BCLR 277 (C). Hereafter referred to as the Grootboom High Court case.

30 The applicants were 510 children and 390 adults. Mrs Grootboom brought the application before the High Court.

31 Grootboom High Court case par 227A, and see the Grootboom case par [4] and [13]. Notably, the Constitutional Court made no distinction between the term "housing" and the term "shelter".

32 Grootboom High Court case par 278B.

33 Grootboom High Court case par 286G-H.

34 Grootboom High Court case par 286H-J. See also De Waal, Currie and Erasmus Bill of Rights 464. 
An order, which enforces a child's right to shelter, should take account of the need of the child to be accompanied by his or her parent. Such an approach would be in accordance with the spirit and purport of section 28 as a whole.

The order made by the Court can be summarised as follows: (a) children must be afforded rudimentary protection from the elements in terms of section 28(1)(c) by the state; (b) the applicant parents are entitled to be accommodated with their children in the mentioned shelter, until the parents are able to shelter their own children; and (c) the state is bound to provide this rudimentary shelter irrespective of the availability of resources.

Government appealed to the Constitutional Court against this decision.

Even though the High Court order was made in terms of section 28, the Constitutional Court found it appropriate to analyse the obligations imposed by section 26 in order to determine whether the Cape Metro Land Programme complied with constitutional requirements. The Court found that section 26 does impose a positive duty on the state to provide everyone, including children, with access to adequate housing. However, this duty is subject to the provisions of section 26(2), therefore, the state must provide for the realisation of this right by means of reasonable legislative and other measures in a progressive manner within its available resources. ${ }^{38}$ Thus, the Court concurred with the High Court's conclusion that no one is entitled to access to housing on demand. However, the Cape Metro Land Programme as the measure taken in order to realise the right to access to adequate housing, was analysed by the Court and found to be unreasonable due to the fact that it did not provide for emergency housing for people in desperate need, i.e. the children.

The Constitutional Court then turned to section 28(1)(c) and the right to shelter. The Court rejected the High Court's interpretation of section 28(1)(c), which allowed parents to receive shelter also along with their children. The Court reasoned that the decision would produce an anomalous result: ${ }^{40}$

35 Grootboom High Court case par 288D-F.

36 Grootboom High Court case par 293H-J.

37 Grootboom Constitutional Court case par [20].

38 Grootboom Constitutional Court case par [34-69].

39 Grootboom Constitutional Court case par [69].

40 Grootboom Constitutional Court case par [71]. 
case by the rights of children to get shelter on demand from the state. Moreover, children would be stepping-stones to housing for their parents instead of being valued for who they are.

Section 28(1)(c) must be read together with section 28(1)(b), which ensures that children are properly cared for by their parents or family, and that they receive appropriate alternative care by the state in the absence of parents or family. According to the Constitutional Court, ${ }^{42}$ subsection (1)(b) defines those responsible for giving care, and subsection (1)(c) lists various aspects of the care entitlement. It then follows that these provisions contemplate that the primary responsibility for care giving, such as providing shelter, is imposed on the parents or family of the children, and only alternatively on the state if the parents are unable to fulfil their duties or if the child has been removed from their care. In other words, the state is only obligated in terms of section 28 to provide shelter to children without parents or children in child-headed households, and not to children and their parents.

This does not mean that the state has no responsibilities toward children living with their parents. The state must provide the legal and administrative infrastructure necessary to ensure that children are protected as envisaged by section 28. Passing the necessary laws, and creating enforcement mechanisms would normally fulfil this obligation. In addition, the state must fulfil its duties to provide families with access to land (section 25), access to adequate housing (section 26), as well as access to adequate health services, food, water, and social security ${ }^{45}$ (section 27) within reasonable progressively available resources.

To summarise, the Constitutional Court confirmed that the primary duty to provide children with care such as envisaged by the Constitution in section 28(1)(c) is imposed on the parents. However, in order for parents to provide the primary care for children, the state must create the framework in which the right conferred upon everyone by section 26 can be progressively realised. Thus, the Court rectified the High Court's erroneous assumption that parents along with their children are entitled to shelter in terms of section 28(1)(c). It is then arguable that

41 Grootboom Constitutional Court case par [76].

42 Grootboom Constitutional Court case par [76].

43 Grootboom Constitutional Court case par [77].

44 Grootboom Constitutional Court case par [77] and [79], this was confirmed in the Minister of Health v Treatment Action Campaign 200210 BCLR 1033 (CC) par [76-77]. Hereafter referred to as TAC case.

45 Khosa v Minister of Social Development CCT 12/03 and Mahlaule v Minister of Social Development CCT 13/03 heard on 13 and 30 May 2003 and decided on 4 March 2004. Hereafter referred to as the Khosa and Mahlaule case. 46 Grootboom Constitutional Court case par [78-79]. Also, see TAC case par [77-78]. 
the measures taken to realise section 26 indirectly provide for the realisation of section 28(1)(c). However, in instances where the parents of children are unable to provide the necessary care, or the children have been removed form parental care, the state has a direct responsibility to ensure the effective realisation of section 28(1)(c).

The Constitutional Court further stated that even children do not have a right to be provided with shelter on demand in terms of section 28(1)(c) by the state. This entails that the state's obligations concerning this internally qualified right of children as envisaged by the High Court order are in some ways restricted. The following section will focus on the limitations placed on the state's obligations in respect of section 28(1)(c).

\subsection{Limiting children's right to basic shelter}

It is submitted in concurrence with other writers, as well as the Grootboom case, that section 28(1)(c) is limited in much the same way as the other socio-economic rights in the Constitution in so far as the state must take reasonable legislative and other measures within available resources to realise the right to basic shelter progressively.

\subsubsection{Reasonable legislative and other measures}

According to the Constitutional Court in the Grootboom case, the key to the justiciability of all socioeconomic rights is the standard of reasonableness:

\footnotetext{
The precise contours and content of the measures to be adopted are primarily a matter for the legislature and the executive. However, they must ensure that the measures they adopt are reasonable. A court considering reasonableness will not enquire whether other more desirable or favourable measures could have been adopted, or whether public money could have been better spent. The question would be whether the measures that have been adopted are reasonable. It is necessary to recognise that a wide range of possible measures could be adopted by the state to meet its obligations. Many of these measures would satisfy the
} 
requirement of reasonableness. Once it has been shown that the measures do so, this requirement is met.

The formulation of the measures taken is only the first stage in meeting the state's obligation toward children. These measures should also be implemented and, therefore, the implementation should be reasonable. An otherwise reasonable measure that is not implemented reasonably will not constitute constitutional compliance. ${ }^{49}$ Therefore, the Court stated in the Grootboom case that measures taken, which ignore the plight of those most in need (i.e. the children) could not be reasonable because it would be in conflict with the constitutional obligation to respect inter alia human dignity.

This qualification provides for the formulation and implementation of legislative and other measures in order to realise the right to have access to adequate housing. The question is whether legislative measures are sufficient, or whether the incorporation of other measures is mandatory. ${ }^{51}$ In the Grootboom case, the Court concluded that legislative measures by themselves would not be sufficient to constitute constitutional compliance, therefore, legislative measures will most likely be supported by programmes and policies implemented by the executive. Furthermore, the legislative and other measures implemented must entail a coordinated and comprehensive programme determined by all three spheres of government in consultation with each other as contemplated by Chapter 3 of the Constitution. The Constitutional Court in the Grootboom case also confirmed this.

The state's obligation to take these reasonable measures means in the first place that a legal framework must be created in which an individual through state assistance can realise his/her rights. De Vos submits that this obligation also entails that the state should provide for the

48 Grootboom Constitutional Court case par [41]. The importance of the standard of reasonableness has also been emphasised in TAC case par [68]. See also Davis, Cheadle and Haysom Fundamental Rights 347; Khosa and Mahlaule case par 48.

49 Grootboom Constitutional Court case par [42].

50 Grootboom Constitutional Court case par [44]. See also De Waal, Currie and Erasmus Bill of Rights 440, Davis, Cheadle and Haysom Fundamental Rights 348-349, Liebenberg 1995 SAJHR 365; Khosa and Mahlaule case par 72: "As far as the applicants (non-citizens) are concerned, the denial of the right is total and the consequences of the denial are grave. They are relegated to the margins of society and are deprived of what may be essential to enable them to enjoy other rights vested in them under the Constitution. Denying them their right under section 27(1) therefore affects them in a most fundamental way. In my view this denial is unfair."

51 De Vos 1997 SAJHR 95; De Waal, Currie and Erasmus Bill of Rights 439.

52 Grootboom Constitutional Court case par [42-43].

53 Grootboom Constitutional Court case par [40].

54 De Waal, Currie and Erasmus Bill of Rights 437.

55 De Vos 1997 SAJHR 95. 
appropriate judicial remedies to enable the rights in question to be enforced. This means that the courts can require explanation from the state of the measures taken to fulfil its duties. Furthermore, the courts may also require the state to give an account of its progress in implementing the measures. These reasons and explanations given by the state can also be evaluated by the courts for their reasonableness.

\subsubsection{Progressive realisation}

The term "progressive realisation" can be understood as a formulation which grants the state a margin of discretion in selecting the means and time frame in which the right to basic shelter must be realised. Furthermore, the inclusion of this phrase shows that it was contemplated that the rights could not be realised immediately due to their pragmatic nature.

This provision is sometimes seen as an escape clause for the state to evade the fulfilment of its constitutional obligations by postponing it to some unspecified time in the future. It is submitted that this is not the case. The fact that the right of access to adequate housing and the right to basic shelter cannot be realised immediately does not alter the state's obligation to take those steps that are within its power immediately and other steps as soon as possible. In other words, any unreasonable delay or failure to exercise due diligence in adopting measures to secure access to adequate housing/shelter will not meet the requirements of this provision.

In determining the purpose of this provision, the Court in the Grootboom case once again reflected international opinion:

It is a necessary flexible device, reflecting the realities of the real world and the difficulties involved for any country in ensuring the full realisation of economic, social, and cultural rights. On the other hand, the phrase must be read in light of the overall objective of the Covenant, which is to establish clear obligations for State parties in respect of the full realisation of the rights in question. It thus imposes an obligation to move as expeditiously and effectively as possible toward that goal.

56 De Waal, Currie and Erasmus Bill of Rights 439-440.

57 Grootboom Constitutional Court case par [45]. See also De Waal, Currie and Erasmus Bill of Rights 437, 441; De Vos 1997 SAJHR 96; Jansen van Rensburg and Olivier 2001 Law, Democracy and Development 91; Davis, Cheadle and Haysom Fundamental Rights 348.

58 De Waal, Currie and Erasmus Bill of Rights 438; De Vos 1997 SAJHR 96; Davis, Cheadle and Haysom Fundamental Rights 348.

59 Grootboom Constitutional Court case par [45]. 
The inclusion of this provision qualifies the state's obligation by taking into account the harsh realities of the world. However, the state must still show that it is making progress toward the full realisation of the right to basic shelter. Therefore, the right to adequate housing/basic shelter may not without good reason be subjected to what is termed deliberately retrogressive measures. ${ }^{61}$ These measures are measures, which have the effect of denying individuals their existing access to adequate housing/shelter, water, food or health services. ${ }^{62}$ A clear example of such a violation is found in the Grootboom case where the local authority evicted a group of squatters including children and demolished their squatter camp without providing emergency alternative accommodation. ${ }^{63}$ Thus, the state infringed upon the rights of a group of children in such a way that their existing access to such shelter was diminished. This was caused by the fact that the state did not provide emergency shelter to the children.

\subsubsection{Within available resources}

This provision is clearly intended to avoid unrealistic demands on the state. In the Soobramoney case, the Court stated: ${ }^{64}$

What is apparent from these provisions is that the obligations imposed on the state by sections 26 and $27 \ldots$ are dependent upon the resources available for such purposes, and that the corresponding rights themselves are limited by reason of lack of resources. Given this lack of resources and the significant demands on them that have already been referred to, an unqualified obligation to meet these needs would not presently be capable of being fulfilled.

This provision recognises that the extent of fulfilment of the rights reflects the practical economic and political reality that is the economy in which the state operates. Once again it must be stressed that this provision does not mean that the state can escape the fulfilment of its duties. In particular, resource scarcity does not relieve the state of its duty to fulfil its core

60 For example, the state must show that it has paid specific attention to providing safe housing to children living in child headed households. De Vos 1997 SAJHR 97; De Waal, Currie and Erasmus Bill of Rights 442.

61 United Nations Committee on Economic, Social and Cultural Rights General Comment 3 at 45 par 9.

Herein after referred to as UN General Comment 3.

62 De Waal, Currie and Erasmus Bill of Rights 434-435.

63 UN General Comment 3 as referred to in Grootboom Constitutional Court case par [88].

64 Soobramoney $v$ Minister of Health, KwaZulu-Natal 19981 SA 765 (CC) par [11]. Hereafter referred to as the Soobramoney case. Quoted with approval in the Grootboom Constitutional Court case par [47]. 
minimum obligations. ${ }^{65}$ According to the Committee on Economic, Social, and Cultural Rights, ${ }^{66}$ each state party has a minimum core obligation to ensure the satisfaction of, at the very least, minimum essential levels of all the socio-economic rights including the right to access to adequate housing and children's right to basic shelter.

Even when resources are scarce, the obligation to ensure the minimum essential levels of the right to basic shelter/access to housing and other socio-economic rights does not fall away. In order to attribute its failure to meet its minimum core obligations, a state must demonstrate that every effort has been made to use all resources that are available in an effort to ensure the realisation of, at least, the minimum essential level of the relevant right. However, even in such circumstances the state must strive to ensure the widest possible enjoyment of the relevant rights. ${ }^{68}$ It is quite clear that the obligation to ensure progressive realisation and to do so within available resources are interlinked. In other words, the state cannot ensure the progressive realisation without taking into account the availability of resources. Moreover, the availability of resources will determine the pace at which these rights can be progressively realised.

In the Grootboom case, the Court declined an open invitation to establish a minimum core obligation in respect of the right of access to adequate housing due to the complexity of the task. ${ }^{69}$ Instead, the Court found that the real question was whether the measures taken to realise these rights are reasonable. ${ }^{70}$ The learned Yacoob J indicated that evidence in a particular case might show that there is a minimum core of a particular service that should be taken into account in determining whether measures adopted by the state were reasonable. However, the socio-economic rights of the Constitution should not be construed as entitling everyone to

65 De Vos 1997 SAJHR 97-98; Davis, Cheadle and Haysom Fundamental Rights 349; De Waal, Currie and Erasmus Bill of Rights 443; De Villiers 1996 TSAR 696-697; Liebenberg 1995 SAJHR 366.

66 UN General Comment 3, as quoted by the Constitutional Court in the Grootboom case par [29].

67 Grootboom Constitutional Court case par [31], and TAC case par [26]. See also De Waal, Currie and Erasmus Bill of Rights 438; Davis, Cheadle and Haysom Fundamental Rights 348-349; De Vos 1997 SAJHR 98; Liebenberg 1995 SAJHR 366367.

68 Grootboom Constitutional Court case par [31].

69 Grootboom Constitutional Court case par [32] the Court explained its reason for not determining a minimum core obligation in terms of s 26: "It is not possible to determine the minimum threshold for the progressive realisation of the right of access to adequate housing without first identifying the needs and opportunities for the enjoyment of such right. These will vary according to factors such as income, unemployment, availability of land and poverty. All this illustrates the complexity of the task of determining a minimum core obligation ... without having the requisite information on the needs and the opportunities for the enjoyment of this right. The Committee developed the concept of minimum core over many years of examining reports by reporting states. This Court does not have comparable information."

70 Grootboom Constitutional Court case par [33]. 
demand that the minimum core be provided to them. ${ }^{71}$ Therefore, the Court treated minimum core as being related to reasonableness under section 26(2), and not as a self-standing right under section 26(1).

Justice Sachs in the Soobramoney case emphasised that the state has to manage its limited resources in order to address the claims of people, including children, who are in need:

The fact that resources are limited will require that the state must adopt a holistic approach to the larger needs of society rather than focus on the specific needs of particular individuals within a society.

To summarise, the Constitutional Court found that the realisation of socio-economic rights, and by association, children's right to basic shelter is subject to, inter alia the availability of resources among other equally important factors. In order to constitute constitutional compliance, the state must at least attempt to ensure the realisation of the minimum essential levels necessary for the enjoyment of the relevant right. The Court declined to determine a minimum core in respect of the right of access to adequate housing, opting rather to emphasise the requirement of reasonableness. Therefore, as explained, the minimum core obligation may be used as a measuring stick when determining the reasonableness of a particular measure taken.

\subsubsection{Right of access to}

Article 11(1) of the International Covenant on Economic, Social and Cultural Rights ${ }^{74}$ provides for the right to adequate housing as opposed to section 26(1) of the Constitution, which provides for the right of access to adequate housing. Initially this has been understood

71 Grootboom Constitutional Court case par [33], see also TAC-case par [34].

72 It must be remembered that s 26(1) and 26(2) do not give rise to self-standing rights. These rights should be read together as defining the scope of the positive rights and the corresponding obligations on the state to 'respect, protect, promote, and fulfil' such rights. See Grootboom Constitutional Court case par [34]. This is also the case regarding s 27 of the Constitution as concluded in the TAC case. Here the argument was that s 27(1) and 27(2) were distinct rights and created two obligations on the state: one to give effect to s 27(1), and the other to do so through 'reasonable legislative and other measures, within its available measures'. The obligation created by s 27(1) has a minimum core to which everyone in need is entitled. For a detailed discussion, see TAC case par [26-39]. This argument was substantially similar to the one put forward in the Grootboom case, therefore, it is not surprising that the Court followed its earlier conclusion that ss (1) and (2) are linked.

73 Soobramoney case par [31].

74 International Covenant on Economic, Social and Cultural Rights, adopted and proclaimed by the United Nations General Assembly Resolution 2200 A (XXI) of 1966. Hereafter referred to as the ICESCR. South Africa has signed the Covenant in 1994, but has not yet ratified it. 
as an attempt to avoid an interpretation that this section creates and unqualified obligation on the state to guarantee free housing on demand to everyone.

However, in the Grootboom case, the Court stated that the qualification of the right to housing recognises that housing entails more than bricks and mortar; it requires available land, appropriate services such as the provision of water and the removal of sewage, and the financing of all these, including the building of the house itself. A right of access to adequate housing/shelter suggests that it is not only the state that is responsible for the provision of houses, but that other members of society must be enabled by legislative and other measures to provide housing/shelter. Thus, the state must create the infrastructure, in which the right to adequate housing/shelter can be realised, while taking into account the different economic levels in society. This is in line with the state's direct and indirect duty in terms of section 28(1)(c) as explained above.

\subsection{Enforcement of section 28(1)(c)}

The implementation and successful enforcement of children's socio-economic rights, such as the right to basic shelter necessitates integrated development strategies. There is a growing awareness that the purpose of development work is to promote and to protect human rights - specifically social, economic and cultural rights. What is proposed is a four-step planning and implementation strategy.

- Firstly, the nature of the existing situation with respect to the right to basic shelter must be ascertained. The object of this analysis would be to identify the key problems (such as homelessness and overpopulation), which need to be addressed in order to facilitate the progressive realisation of the right in question effectively.

- Secondly, effective planning of action in the children's rights field requires the setting of goals and standards. In other words, a child's right to basic shelter needs to be converted into verifiable goals or objectives, achievable within agreed upon periods.

75 Davis, Cheadle and Haysom Fundamental Rights 345.

76 Grootboom Constitutional Court case par [35]. See also Jansenvan Rensburg and Olivier 2001 Law, Democracy and Development 92.

77 Himes Implementing the CRC 21. 78 Id 21. 79 Id 21-22. 
- Thirdly, a comprehensive action plan has to be developed to reach the set goals. This action plan can manifest itself in reasonable legislative and other measures, which recognise that the implementation thereof is subject to resource availability. In this regard, it must be remembered that all measures taken whether legislative or otherwise must be reasonable in their conception and formulation.

The fourth step entails the effective implementation of these measures.

Two distinct kinds of norm enforcement play a role in the implementation of socio-economic rights in South Africa. In the first instance, focus will be on the adversarial enforcement mechanisms of the courts. Thereafter, inquisitorial mechanisms such as the South African Human Rights Commission will be discussed.

\subsubsection{Judicial enforcement}

In Fose v Minister of Safety and Security ${ }^{82}$ the Constitutional Court stated that, due to the supremacy of the Constitution, all unconstitutional law or conduct is invalid. This is in line with section 172(1)(a), which provides that, when deciding a constitutional matter, a court must declare that any law or conduct that is inconsistent with the Constitution, is invalid to the extent of its inconsistency.

When applied to the enforcement of children's right to basic shelter, section 172(1)(a) begs the argument that a programme which is designed to facilitate access to adequate housing in terms of section 26(1), read together with section 26(2), and does not expressly provide for the needs of children, or fail to regard their interests as paramount, does not constitute constitutional compliance, and is therefore invalid. The same argument can be voiced in regard to children without parents to whom the state has a direct responsibility to provide the necessary shelter in terms of section 28(1)(c).

From reading the rest of section 172(1) it becomes clear that the declaration of invalidity is not the only remedy a court can award. Section 172(1)(b) provides that "a court may make any

80 Grootboom Constitutional Court case par [42].

81 Himes Implementing the CRC 22.

82 Fose v Minister of Safety and Security 19973 SA 786 (CC) par [87]. Hereafter referred to as the Fose case.

83 S 2 of the Constitution states: "This Constitution is the supreme law of the Republic; law or conduct inconsistent with it is invalid, and the obligations imposed by it must be fulfilled."

84 De Waal, Currie and Erasmus Bill of Rights 170-171; Davis, Cheadle and Haysom Fundamental Rights 351. 
order that is just and equitable". Furthermore, section $38^{85}$ of the Constitution provides for "appropriate relief", and specifically refers to a declaration of rights where fundamental rights have been infringed. In the Fose case, the Court concluded that:

Appropriate relief will in essence be relief that is required to protect and enforce the Constitution. Depending on the circumstances of each particular case, the relief may be a declaration of rights, an interdict, a mandamus, or such other relief as may be required to ensure that the rights enshrined in the Constitution are protected and enforced. If it is necessary to do so, the courts may even have to fashion new remedies to secure the protection and enforcement of these all-important rights.

The Court's statement regarding appropriate relief makes it clear that the object in awarding any remedy must be to protect the rights contained in the Constitution effectively. This means that the remedy must at least vindicate the Constitution and deter future infringements. Specific constitutional remedies used by the Court include the following: ${ }^{88}$ Orders of invalidity; ${ }^{89}$ the development of the common law to give effect to the constitutional rights; ${ }^{90}$ constitutional damages; ${ }^{91}$ interdicts; ${ }^{92}$ and a declaration of rights.

The High Court in Grootboom v Oostenberg Municipality ${ }^{94}$ extensively used the structured interdict ${ }^{95}$ to enforce a positive obligation. The Court found that the conditions under which the

85 S 38 provides: "Anyone listed in this section has the right to approach a competent Court, alleging that a right in the Bill of Rights has been infringed or threatened, and the Court may grant appropriate relief, including a declaration of rights."

86 Fose case par [19].

87 Fose case par [96]. See also the discussion in De Waal, Currie and Erasmus Bill of Rights 173; Davis, Cheadle and Haysom Fundamental Rights 351; Sanderson v Attorney General, Eastern Cape 19982 SA 38 (CC).

88 Jansen van Rensburg and Olivier 2001 Law, Democracy and Development 95; De Waal, Currie and Erasmus Bill of Rights 451-454; Davis, Cheadle and Haysom Fundamental Rights 354.

89 In terms of s 172(1) (b) a court can make an order limiting the retrospective effect of the declaration of invalidity, also a court can make an order suspending the declaration of invalidity, to allow the competent authority to correct the defect. See De Waal, Currie and Erasmus Bill of Rights 175-188.

90 S 173 of the Constitution; see also Carmichele v Minister of Safety and Security 20014 SA 938 (CC) for the Court's use of this inherent power.

91 De Waal, Currie and Erasmus Bill of Rights 188-191; see also Fose v Minister of Safety and Security 19973 SA 786 (CC).

92 De Waal, Currie and Erasmus Bill of Rights 191-193; see City Council of Pretoria v Walker 19954 SA 631 (CC).

93 This remedy, in terms of s 38, is only applicable to infringement of rights entrenched in the Bill of Rights. In JT Publishing $v$ Minister of Safety and Security 19973 SA 514 (CC) par [15], the Court held that a declaratory order is a discretionary remedy, in the sense that the court is not obliged to make such order even if the matter in question is capable of being answered in that way. See De Waal, Currie and Erasmus Bill of Rights 193-194.

94 Grootboom High Court case. 
squatters were living, were a violation of the right of children to shelter in terms of section 28(1)(c). Reference was also made to section 26 in respect of the conditions in which the children's parents were living. According to the High Court, section 38 and section 172 of the Constitution permit the issuing of an order, which identifies the violation of a constitutional right and then defines the reform that must be implemented while affording the responsible agency the opportunity to choose the means of compliance. In this case, the High Court ordered the state to provide the necessary emergency shelter to the children and their accompanying parent(s).

On appeal, the Constitutional Court held in the Grootboom case that the High Court's interpretation of the relevant constitutional provisions was incorrect. The right to housing did not give the applicants a right to claim housing immediately on demand. Therefore, the remedy for the infringement could not put the applicants in a preferential position as opposed to people in similar situations that were not party to the litigation. ${ }^{98}$ The Constitutional Court held that due to the pragmatic nature of socio-economic rights, it was necessary and appropriate to award a declaratory order.

The question may be asked whether the Court, in respect of socio-economic rights in general, can only make declaratory orders, or can it, when appropriate implement mandatory orders. It must, however, be remembered that due to South Africa's system of judicial hierarchy, the Constitutional Court judgment represents the present legal position.

In Minister of Health $v$ Treatment Action Campaign ${ }^{100}$ counsel for government contended that if the Court should find that government policies fall short of the constitutional requirements, the only competent order that a court can make is to issue a declaration of rights to that effect. ${ }^{101}$ The making of government policy is a prerogative of the executive and not the court, therefore, so the argument went, any other order, which requires the executive to pursue a

95 A structured interdict is employed to direct a violator to take steps to rectify a violation of the rights under the court's supervision.

96 Grootboom High Court case par 293H-J. See also Davis, Cheadle and Haysom Fundamental Rights 354.

97 Grootboom High Court case par 293I.

98 Grootboom Constitutional Court case par [79-81].

99 Grootboom Constitutional Court case par [99].

100 Minister of Health v Treatment Action Campaign 200210 BCLR 1033 (CC) par [96].

101 See also Davis, Cheadle and Haysom Fundamental Rights 354. 
particular policy, was undemocratic in so far that it is inconsistent with the doctrine of separation of powers.

The Court's obligation to declare unconstitutional law or conduct invalid in terms of section 172 is also applicable to government policies. This then serves as a constitutional mandate for the intrusion upon the executive's domain. The Court further held that that there is no merit in the distinction drawn between declaratory and mandatory orders - even a simple declaration of rights might have budgetary implications. $^{103}$ Referring to the Fose case, the Court emphasised that it is under a duty to ensure that appropriate and effective relief is granted. The nature of the right infringed, and the nature of the infringement will provide guidance as to the appropriate relief in a particular case.

Therefore, the Court rejected the argument that it could only make declaratory orders due to the contention that mandatory orders are inconsistent with the doctrine of separation of

powers.

In this respect the Court also stated that the power to grant mandatory relief, where appropriate, might include the exercise of some sort of judicial supervisory jurisdiction. ${ }^{105}$ This entails that the courts would give orders directing the legislature and executive branches of government to bring about reforms defined in terms of their objective and then to retain such supervisory jurisdiction as to the implementation of those reforms. ${ }^{106}$ In other words, the Court or other institution may retain jurisdiction so as to ensure and supervise the implementation of the ordered reforms. An example of this new practice is found in the Grootboom case, where the Constitutional Court awarded the Human Rights Commission supervisory jurisdiction to ensure the effective implementation of the necessary policy reforms.

102 TAC case par [97]. This is similar to the Court's conclusion in the First Certification judgment, where it was argued that socio-economic rights were not justiciable because it is inconsistent with the doctrine of separation of powers. Certification of the Constitution of the Republic of South Africa, 199619964 SA 744 (CC) par [77].

103 TAC case par [99].

104 TAC case par [106].

105 TAC case par [104].

106 Jansen van Rensburg and Olivier 2001 Law, Democracy and Development 95; Jansen van Rensburg Sosiale Sekerheid 247.

107 Grootboom Constitutional Court case par [97]. 


\subsubsection{Monitoring the enforcement of socio-economic rights}

To ensure the effective realisation of the totality of obligations engendered by the economic, social, and cultural rights of everyone, especially those conferred upon children, a mix of official and nongovernmental monitoring mechanisms are necessary.

The South African Human Rights Commission was established by section 184 of the Constitution, which serves as a similar monitoring mechanism on municipal level. Section 184(3) provides:

Each year, the Human Rights Commission must require relevant organs of state to provide the Commission with information on the measures that they have taken towards the realisation of the rights in the Bill of Rights concerning housing, health care, food, water, social security, education, and the environment. 09

It is submitted that the objective of these reporting procedures is inspection and introspection. The performance of the relevant state organ is assessed from the outside by the Human Rights Commission, but in the process, the organ itself is also compelled to look at what it has achieved in respect of children's socio-economic rights in a critical way. In this way an obligation of internal and external justification is placed on the state. ${ }^{110}$ Though the Human Rights Commission will most likely never be directly involved in the enforcement of socioeconomic rights in general, the yearly reports received by them may play a vital role in litigation. From these reports the progress made in the realisation of socio-economic rights can be judged. The reports may also provide the basis for the elaboration of government policies in the future.

In the South African Human Rights Commission's most recent findings and recommendations concerning the measures adopted by government to execute its obligation in terms of section 26 the Commission supported the Court's conclusion in the Grootboom case that the question in this regard is whether the measures adopted establish an integrated coherent programme

108 Jansen van Rensburg Sosiale Sekerheid 305-306, Himes Implementing the CRC 22; Franklin Children's Rights 15.

109 Own emphasis.

110 Kollapen Annual Economic and Social Rights Report 13 of the South African Human Rights Commission (SAHRC: 2000-2002).

111 Jansen van Rensburg Sosiale Sekerheid 420-421; De Vos 1997 SAJHR 99. 
involving all three spheres of government, directed towards the progressive realisation of the right of access to adequate housing within the State's available resources.

The Court in the Grootboom case stated that housing involves more than bricks and mortar. ${ }^{113}$ The Commission has accepted this statement when it stated that the National Department of Housing should understand that housing is not merely about numbers and targets, but involves the quality of the living environment. $^{114}$ In this regard, the Commission stated that housing projects should look after the ecological support system upon which all life depends. ${ }^{115}$ The Commission further emphasised with reference to the Grootboom case, ${ }^{116}$ that the programme developed to address emergency housing needs should be sufficiently flexible to respond to those in desperate need and to cater for immediate and shortterm requirements whenever such need arises.

'Habitability' is considered one of the factors when determining whether a particular form of shelter constitutes adequate housing. Adequate housing will be considered habitable if it "provides the inhabitants with adequate space and protection from cold, damp, heat, rain, wind or other threats to health, structural hazards and disease vectors". ${ }^{118}$ Unfortunately, the Commission concluded that most of the new housing projects in South Africa fall short of this definition. ${ }^{119}$ It is not surprising that the Commission expressly stated that this problem is one of the major barriers facing the improvement of the quality of life for the poor, especially children.

The Commission further listed several aspects detrimental to the successful implementation of measures adopted to facilitate the realisation of section 26 that should be remedied. ${ }^{121}$ These aspects include the unavailability of suitable land, the delay in transferring land to the beneficiaries due to administrative problems, problems due to inexperienced developers and

112 Kollapen Annual Economic and Social Rights Report 47 (SAHRC: 2000-2002).

113 Grootboom Constitutional Court case par [35].

114 Id par [35].

115 Kollapen Annual Economic and Social Rights Report 59 (SAHRC: 2000-2002).

116 Grootboom Constitutional Court case par [66].

117 Kollapen Annual Economic and Social Rights Report 51 (SAHRC: 2000-2002).

118 Id 51 (SAHRC: 2000-2002).

119 Id 51 (SAHRC: 2000-2002).

120 Id 59-60 (SAHRC: 2000-2002). Own emphasis.

121 Id 52-53 and 60 (SAHRC: 2000-2002). 
quality of products, issues concerning the security of tenure and inadequate budget allocations.

Most importantly for the purpose of this article is the fact that the Commission found that most of the submitted reports do not clearly articulate the measures and the extent of the impact of the measures adopted on the lives of the vulnerable groups within their areas of jurisdiction. ${ }^{123}$ The National Housing Subsidy Scheme serves as example in that it requires beneficiaries to be over the age of twenty-one and legally competent to qualify for housing subsidies. This has the direct effect of excluding individual children and child-headed households. ${ }^{124}$ The Commission strongly recommended that national government must adopt policies and enact legislation or develop a strategy to alleviate difficulties facing these children.

\section{Conclusion: Findings and Recommendations}

Poverty is a worldwide phenomenon, which is most evident in third world countries. South Africa falls in this category as a developing state. Children being the most vulnerable members of society are the one's most affected by living in poverty. This unacceptable situation can inter alia be attributed to the disastrous effects of Apartheid. During this unfortunate period in our nation's history millions of people were unjustly evicted from their homes and forced to live in deplorable conditions. Moreover, many of these people were left homeless or without the necessary adequate shelter. Children who were born into these circumstances were denied basic resources such as proper shelter, food, water and health care services.

These unfortunate circumstances existed at the adoption of South Africa's democratic Constitution. The preamble of the Constitution reaffirms government's commitment to heal the inequalities of the past and improve the quality of life of all citizens. The Constitution is based on certain fundamental values, most importantly, human dignity, freedom and equality. The fact that these values are denied to those people living without access to basic resources such as adequate housing/shelter, food, water or health care services cannot be dismissed. To facilitate South Africa's development as a democratic state based on human dignity, freedom and equality, the problem of poverty must be addressed.

122 Id 52-53 (SAHRC: 2000-2002).

123 Id 56 (SAHRC: 2000-2002).

124 Id 56 (SAHRC: 2000-2002).

125 Id 61 (SAHRC: 2000-2002). 
The Constitutional Court, in the Grootboom case, has recently stated that the effective realisation of socio-economic rights is key to the advancement of a value based democratic South Africa. The Constitution provides everyone with fundamentally entrenched socioeconomic rights by virtue of sections 25(5), 26 and 27. Furthermore, section 28(1)(c) provides children with additional socio-economic rights and the right to basic shelter is expressly provided for.

By virtue of section 28(1)(b) the primary responsibility to provide children with the necessary adequate housing/shelter is vested in their parents, unless the parents are unable to fulfil their duty or the children are removed from their care. This provision is in line with the binding principles of the Convention on the Rights of the Child. This does not in the least mean that the state has no responsibilities to children living with their parents. The state must still provide the framework in which parents can facilitate the realisation of their children's rights. The state can fulfil this obligation by taking reasonable legislative and other measures within its available resources to realise everyone's right of access to adequate housing progressively. Therefore, it is submitted that the measures taken to realise section 26 also indirectly ensures the realisation of children's right to basic shelter (section 28(1)(c)).

It has been largely accepted by the courts and academics alike that all fundamental human rights are indivisible and interrelated. Clearly then, the state's obligations in terms of section 28(1)(c) cannot be properly interpreted without referring to the interpretation of those obligations conferred upon it by section 26(2) and the other socio-economic rights in the Constitution. Hence, section 28(1)(c) must be seen in the context of the Constitution as a whole. Put simply, the state must take reasonable legislative and other measures within its available resources to realise children's right to basic housing/shelter progressively.

The Constitutional Court in the Grootboom case could not over emphasise the importance of the reasonableness requirement. The Court stated that the legislative and other measures taken to realise the right will not be reasonable if it fails to provide for the protection of those most in need. Thus, it is convincingly argued that measures taken to realise the right of access to adequate housing (thereby, indirectly also realising children's right to basic shelter), which do not consider the interest of children to be paramount, will not constitute constitutional compliance due to lack of reasonableness. 
The state's obligations in this regard are further qualified by the fact that measures have to be taken within available resources. This reflects the reality that is the economy in which the state operates. To comply, the state must show that it, at the very least, satisfies the minimum essential levels necessary for the enjoyment of adequate housing/shelter. This refers to the state's minimum core obligation. Unfortunately, the Constitutional Court in the Grootboom case, recently refused an open invitation to define the minimum core in respect to section 26. The Court stated with just cause that it did not have sufficient information before it to take on such a daunting task.

While accepting the present legal position, it is submitted that an established minimum core would have some far-reaching advantages such as providing socio-economic rights with more determinacy and certainty. This would have had the effect that goals and strategies in terms of realising the right to adequate housing/shelter could be more realistically established. Hence, legislative and other measures would be much more comprehensive, not to mention effective. Furthermore, defining a minimum core obligation would have greatly eased the enforcement of socio-economic rights as far as the courts would have had a minimum standard against which to judge the measures taken.

The measures taken must then also ensure the progressive realisation of the right in question, i.e. the right of access to adequate housing. This qualification recognises that socio-economic rights cannot be realised immediately and on demand. However, the state must still show that it has at least made some progress toward the full realisation of the right in question.

The realisation of socio-economic rights to alleviate poverty requires an integrated action plan encompassing various strategies, projects and programmes implemented in all three spheres of government. The South African Human Rights Commission has confirmed that every level of government whether national, provincial, or local has a particular role to play in the response to poverty. Thus, the principle of co-operative government is essential.

Children hold our nation's future in their hands. To ensure that our country and its inhabitants reach their full potential, the problem of poverty, especially child poverty and its devastating effects must be seriously addressed. To do this, people on all levels of society need to forgive the past and embrace the future together. The key word is solidarity in a prosperous South Africa. 


\section{Bibliography}

Committee of Inquiry into a Comprehensive System of Social Security for South Africa

Protecting the Children

Committee of Inquiry into a Comprehensive System of Social Security for South Africa "Chapter 7

Protecting the Children" in Transforming the Present - Protecting the Future Consolidated Report

March 2002 (Committee of Inquiry Pretoria 2002)

Davis, Cheadle and Haysom Fundamental Rights Davis D, Cheadle H and Haysom N Fundamental

Rights in the Constitution (Juta Kenwyn 1997)

De Villiers 1996 TSAR De Villiers B "Human rights in developing countries: some crucial issues" 1996

TSAR 679-700

De Vos 1997 SAJHR De Vos P "Pious wishes of directly enforceable human rights?: Social and economic rights in South Africa's 1996 Constitution" 1997 SAJHR 67-101

De Vos 1995 SAPL De Vos P "The economic and social rights of children and South Africa's transitional Constitution" 1995 SAPL 233-259

De Waal, Currie and Erasmus Bill of Rights De Waal J, Currie I and Erasmus G Bill of Rights Handbook $4^{\text {th }}$ ed (Juta Lansdowne 2001)

Franklin Children's Rights Franklin B (ed) The Handbook of Children's Rights Comparative Policy and Practice (Routledge London 1995)

Goldewijk and de Gaay Fortman Where Needs Meet Rights Goldewijk BK and de Gaay Fortman B Where Needs Meet Rights (WCC Publications Geneva 1999)

Himes Implementing the CRC Himes JR (ed) Implementing the Convention on the Rights of the Child: Resource Mobilization in Low-Income Countries (Martinus Nijhoff Publishers Dordrecht 1995)

ICESCR International Covenant on Economic, Social and Cultural Rights (United Nations General Assembly Resolution 2200A (XXI) UN Doc A/6316 of 1966)

Jackson and Jackson Introduction to Political Science Jackson RJ and Jackson D A Comprehensive Introduction to Political Science (Prentice-Hall Inc New Jersey 1997)

Jansen van Rensburg and Olivier 2001 Law, Democracy and Development Jansen van Rensburg L and Olivier MP "Protection and enforcement of the right to social security" 2001 Law, Democracy and 
Development 87-99

Jansen van Rensburg Sosiale Sekerheid Jansen van Rensburg L Die Beregtiging van die Fundamentele Reg op Toegang tot Sosiale Sekerheid (LL D- Thesis RAU Johannesburg 2001)

Kollapen Annual Economic and Social Rights Report Kollapen J 4th Annual Economic and Social Rights Report of the South African Human Rights Commission (2000-2002) (SAHRC Johannesburg 2003)

Liebenberg 1995 SAJHR Liebenberg S "The International Covenant on Economic, Social and Cultural Rights and its implications for South Africa" 1995 SAJHR 359-378

Venter Government and Politics Venter A (ed) Government and Politics in the new South Africa $2^{\text {nd }}$ ed (Van Schaik Publishers Pretoria 2001)

UN General Comment 3 United Nations Committee on Economic, Social and Cultural Rights, General Comment 31990 "The Nature of State Parties Obligations" (UN Doc HRI/Gen 1/Rev 1 at 45 of 1994)

\section{Register of acts}

Child Care Act 74 of 1983 Constitution of the Republic of South Africa 1996

\section{Register of cases}

Carmichele $v$ The Minister of Safety and Security and the Minster of Justice and Constitutional Development 20014 SA 938 (CC)

Certification of the Constitution of the Republic of South Africa, 199619964 SA 744 (CC)

City Council of Pretoria v Walker 19954 SA 631 (CC)

Fose v Minister of Safety and Security 19973 SA 786 (CC)

Government of the Republic of South Africa and Others v Grootboom and Others 200011 BCLR

1169 (CC)

Grootboom v Oostenberg Municipality and Others 20003 BCLR 277 (C)

JT Publishing v Minister of Safety and Security 19973 SA 514 (CC)

Khosa and Others $v$ Minister of Social Development and Others CCT 12/03 heard on 13 and 30 May 2003 and decided on 4 March 2004

Mahlaule and Others v Minister of Social Development and Others CCT 13/03 heard on 13 and 30 May 2003 and decided on 4 March 2004

Minister of Health and Others v Treatment Action Campaign and Others 200210 BCLR 1033

(CC) Sanderson v Attorney General, Eastern Cape 19982 SA 38 (CC) Soobramoney v Minister of 
Health, KwaZulu-Natal 19981 SA 765 (CC)

\section{Register of internet references}

Jansen van Rensburg L "Interpreting socio-economic rights - transforming South African society?" Special ed 16 November 2002 PER [Found on Internet] HYPERLINK http://www.puk.ac.za/law/per/documents/special\%20edition\%202002/linda.doc [Date of use 20 March 2004]

Joint Submission to the Portfolio Committee 2003 Social Development on the Social Assistance Bill 18 September 2003 [Found on Internet] HYPERLINK http://www.pmg.org.za/docs/2003/appendices/030922joint.htm [Date of use 20 March 2004]

May J 1998 Poverty and Inequality in South Africa [Found on the Internet] HYPERLINK http://www.und.ac.za [Date of use 20 May 2003]

Motala S 2001 Poverty and Social Security [Found on Internet] HYPERLINK http://www.childrensrightscentre.co.za/topics/poverty.html [Date of use 20 May 2003]

Streak J 2001 Budget 2001 does little for child poverty [Found on the Internet] HYPERLINK http://www.idasa.org.za [Date of use 20 May 2003]

Streak J 2000 Budget 2000 and Child poverty [Found on the Internet] HYPERLINK http://www.idasa.org.za [Date of use 20 May 2003] 